\title{
CEREBRAL SINOVENOUS THROMBOSIS IN A NEPHROTIC CHILD
}

\author{
Marcelo Masruha Rodrigues ${ }^{1}$, Lilian Rocha Zardini², \\ Maria Cristina de Andrade ${ }^{3}$, Cristina Malzoni Ferreira Mangia ${ }^{3}$, \\ João Tomas de Abreu Carvalhaes ${ }^{4}$, Luiz Celso Pereira Vilanova ${ }^{5}$
}

\begin{abstract}
Nephrotic syndrome in infancy and childhood is known to be associated with a hypercoagulable state and thromboembolic complications, but cerebral sinovenous thrombosis (CST) is a very rare and serious one, with only a few isolated reports in the literature. A case is presented of a 9-year-old boy with nephrotic syndrome that acutely developed signs and symptoms of intracranial hypertension syndrome. CST was diagnosed on cranial CT and MRI and he gradually recovered after treatment with anticoagulants. The diagnosis of CST should be considered in any patient with nephrotic syndrome who develops neurologic symptoms. The discussion of this case, coupled with a review of the literature, emphasizes that early diagnosis is essential for institution of anticoagulation therapy and a successful outcome. This report also illustrates the difficulties that may be encountered in managing such a patient.
\end{abstract}

KEY WORDS: cerebral venous thrombosis, sagittal sinus thrombosis, nephrotic syndrome, child.

\section{Trombose venosa cerebral em uma criança com síndrome nefrótica}

RESUMO - A síndrome nefrótica na criança é sabidamente associada a um estado de hipercoagulabilidade e complicações tromboembólicas, entretanto a trombose venosa cerebral (TVC) é uma complicação muito rara e grave, com poucos relatos na literatura. Relatamos o caso de um menino de 9 anos com síndrome nefrótica que agudamente desenvolveu sinais e sintomas de uma síndrome de hipertensão intracraniana. TVC foi diagnosticada através de CT e IRM de crânio e o paciente gradualmente se recuperou após o tratamento com anticoagulantes. O diagnóstico de TVC deve ser considerado em qualquer paciente com síndrome nefrótica que desenvolva sintomas neurológicos. A discussão deste caso, associada à revisão da literatura, enfatiza que o diagnóstico precoce é essencial para instituição da terapia anticoagulante e para o bom prognóstico. Este relato também ilustra a dificuldade em manejar este tipo de paciente.

PALAVRAS-CHAVE: trombose venosa cerebral, trombose do seio sagital, síndrome nefrótica, criança.

Arterial and venous thromboses are well-recognized classic complications of nephrotic syndrome, however these are far less frequent in children than in adults ${ }^{1}$ Cerebral sinovenous thrombosis (CST) associated with nephrotic syndrome in children is extremely rare and only a few isolated reports exist in the literature ${ }^{2-13}$.

\section{CASE}

A 9-year-old white boy with steroid-responsive nephrotic syndrome of undetermined cause, diagnosed when he was 4-years-old, acutely developed a severe generalized throbbing headache four days prior to admission to the São Paulo Hospital. He described it as continuous, with photophobia and phonophobia, without relieving factors. Eight days prior to the onset of that clinical picture he started with vomiting and upper abdominal pain not related to food intake, with worsening signs and symptoms of nephrotic syndrome. Hewas on tapered treatment with alternate day, single dose of prednisone. An esophagogastroduodenoscopy was performed, disclosing a severe non-erosive gastritis and ranitidine was started. Past medical history was negative for migraine headaches, head trauma, febrile illness, substance abuse, vitamin intake or thrombophlebitis. Family history was unremarkable.

On admission his vital signs were normal. He was generally uncooperative, and appeared to be experiencing significant discomfort. Neurologic examination disclosed

Departments of Neurology / Neurosurgery and Pediatrics, Federal University of São Paulo, São Paulo SP, Brazil: ${ }^{1}$ Resident, Department of Neurology and Neurosurgery; ${ }^{2}$ Resident, Department of Pediatrics; ${ }^{3}$ Associated Physician, Department of Pediatrics; ${ }^{4}$ Associated Professor, Department of Pediatrics; ${ }^{5}$ Associated Professor, Department of Neurology and Neurosurgery.

Received 14 April 2003, received in final form 20 June 2003. Accepted 9 July 2003.

Dr. Marcelo Masruha Rodrigues - Federal University of São Paulo, Division of Child Neurology, Department of Neurology and Neurosurgery - Rua Botucatu 720 - 04023-900 São Paulo SP - Brazil. E-mail: mmasruha@ig.com.br 


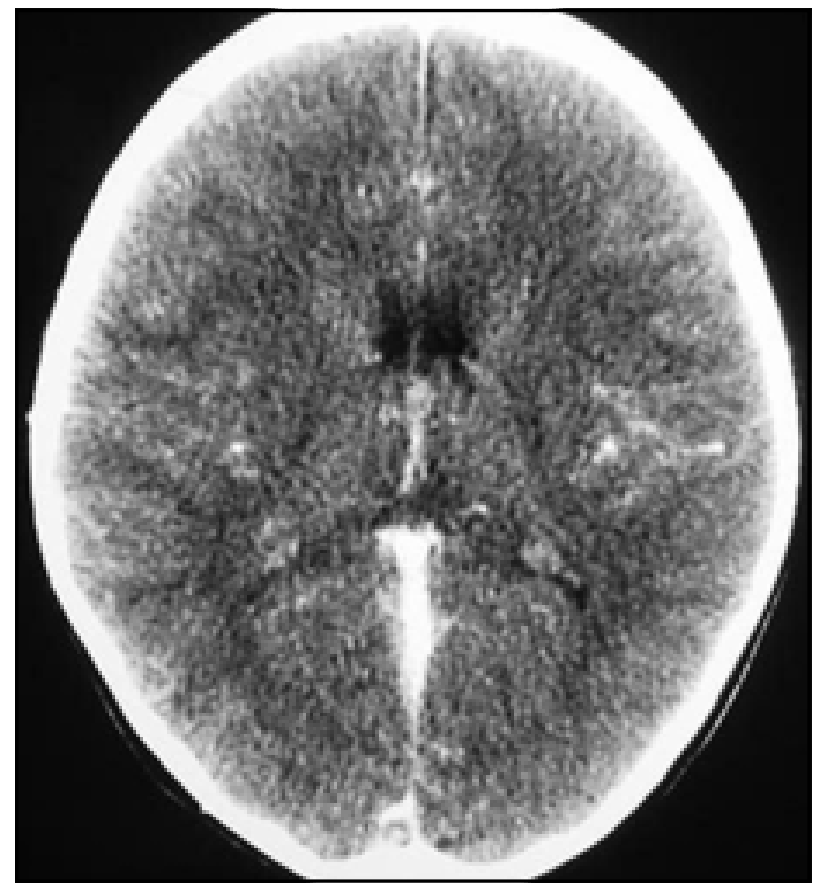

Fig 1 Axial contrast-enhanced cranial CT shows a filling defect in the region of the venous confluence (the empty delta sign) associated with a dilated straight sinus.

remarkable meningeal irritation signs (nuchal rigidity, Brudzinski sign and Kernig sign) and papilledema. The remainder of the examination was within normal limits. Normal values were obtained for the following laboratory data: complete blood count (CBC), serum electrolytes, glucose, urea and creatinine. Serum albumin was $1.7 \mathrm{~g} / \mathrm{dL}$ and $24-$ $\mathrm{h}$ urine protein excretion was $18 \mathrm{~g} /$ day.

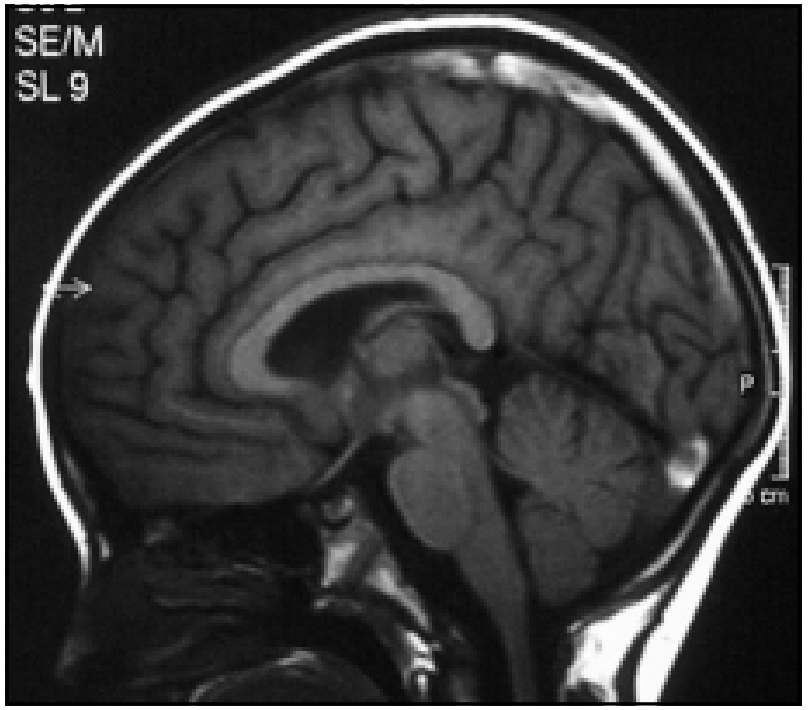

Fig 2 Sagittal T1-W image reveals increased signal intensity within the superior sagittal sinus and in the region of the venous confluence.

Noncontrast-enhanced cranial CT revealed the densetriangle sign and the contrast enhanced phase showed a dilated straight sinus and the empty-delta sign (Fig 1). There was no mass effect, midline shift or venous stroke image. Cranial magnetic resonance imaging (MR) and magnetic resonance venography (MRV) demonstrated superior sagittal and left transverse sinus thrombosis. There were no cerebral parenchyma or brainstem lesions (Figs 2 and 3).

A loading dose of heparin of $50 \mathrm{U} / \mathrm{kg}$ was given IV followed by a continuous infusion of $10 \mathrm{U} / \mathrm{kg}$ per hour and morphine was given to provide analgesia. We

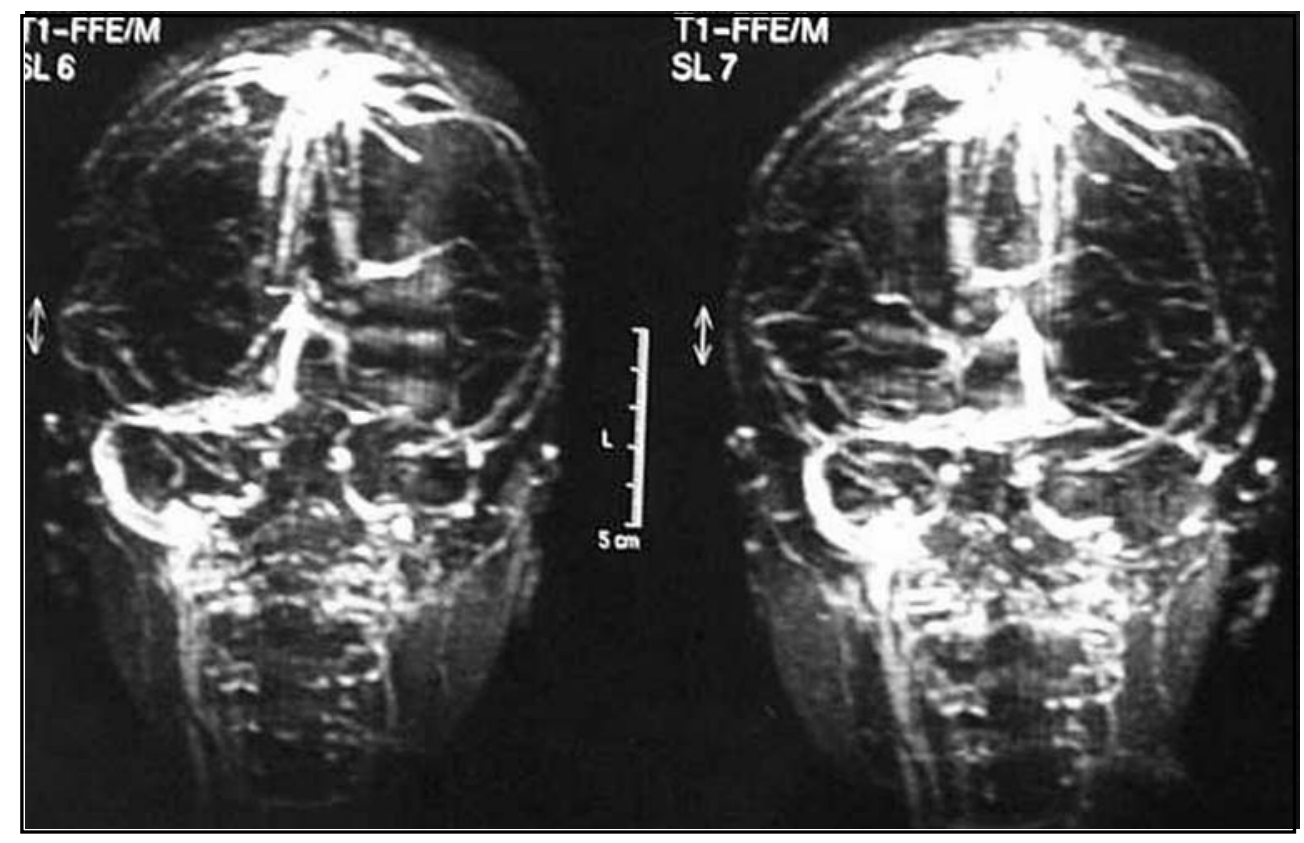

Fig 3. MRV shows dilated cortical veins associated with a filling defect of sagittal superior sinus and absence of flow in left transverse and sigmoid sinus. 
Table 1. Conditions associated with aseptic CST in children.

\begin{tabular}{|c|c|}
\hline 1. Procoagulant drugs & 10. Connective-tissue disease \\
\hline Oral contraceptives & Systemic lupus erythematosus \\
\hline Asparaginase & Behçet disease \\
\hline 2. Head injury and strangulation & Antiphospholipid antibody syndrome \\
\hline 3. Pregnancy and puerperium & 11. Nephrotic syndrome \\
\hline 4. Postoperative states & 12. Hypernatremic dehydration \\
\hline 5. Hematologic disorder & 13. Diabetic ketoacidosis \\
\hline Iron deficiency & 14. Osteopetrosis \\
\hline Sickle cell disease & 15. Abnormal local hemodynamics \\
\hline Beta-thalassaemia major & Arteriovenous malformations \\
\hline Primary or secondary polycythemia & Dural arteriovenous fistula \\
\hline Paroxysmal nocturnal hemoblobinuria & Moyamoya disease \\
\hline 6. Inflammatory bowel disease & Sturge-Weber syndrome \\
\hline Crohn disease & 16. Cancer \\
\hline Ulcerative colitis & 17. Inherited coagulation disorders \\
\hline 7. Perinatal complications (neonatal group) & Factor V (Leiden) mutation \\
\hline Hypoxia at birth & G20210A prothrombin-gene mutation \\
\hline Premature rupture of membranes & Protein S deficiency \\
\hline Maternal infection & Protein C deficiency \\
\hline Placental abruption & Antithrombin III deficiency \\
\hline Gestational diabetes & 18. Allogeneic bone marrow transplantation \\
\hline 8. Homocystinuria & 19. Extracorporeal membrane oxygenation \\
\hline 9. Malnutrition & 20. Idiopathic \\
\hline
\end{tabular}

attempted to maintain the partial thromboplastin time (PTT) between 64 to $80 \mathrm{~s}$, with a control of $32 \mathrm{~s}$. However, despite doses as high as $30 \mathrm{U} / \mathrm{kg}$ per hour, the increase in PTT could not be sustained. The nephrotic state was treated with prednisone ( $2 \mathrm{mg} / \mathrm{kg} / \mathrm{day}$ ) and remission of the nephrotic syndrome occurred 5 days after the institution of that treatment. At this time the desired levels of anticoagulation were achieved and two days later Warfarin at $0,1 \mathrm{mg} / \mathrm{kg} / \mathrm{day}$ was added with successful control of prothrombin time. The child gradually made a complete clinical recovery over 2 weeks.

\section{DISCUSSION}

Cerebral sinovenous thrombosis in children is a rare disorder but one that is increasingly diagnosed because of greater clinical awareness, sensitive neuroimaging techniques, and the survival of children with previously lethal diseases that confer a predisposition to sinovenous thrombosis ${ }^{14}$ It has been recognized since the $19^{\text {th }}$ century, usually associated with trauma or pyogenic infections, like mastoiditis, sinusitis and facial cellulitis. However, the development and use of antibiotics greatly reduced the inci- dence of septic thrombosis ${ }^{15}$ Aseptic CST is now more common and have been reported in association with acute and chronic systemic diseases (Table). Idiopathic CST represents only 3 percent of cases in children ${ }^{14}$.

Nephrotic syndrome is defined by a urinary protein level exceeding $3.5 \mathrm{~g}$ per $1.73 \mathrm{~m}^{2}$ of body-surface area per day. It is associated with a hypercoagulable state arising due to various factors like - low zymogen factors (factor IX and factor XI), increased procoagulatory cofactors (factor $V$ and factor VIII), increased fibrinogen levels, decreased coagulation inhibitors: antithrombin III (but protein C and protein S increased), altered fibrinolytic system ( $\alpha 2$-antiplasmin increased and plasminogen decreased), increased platelet reactivity and altered endothelial-cell function ${ }^{16}$. Dehydration secondary to gastritis with vomiting and steroid therapy were additional risk factors in our patient.

Thrombosis of various vessels has been reported, but CST associated with nephrotic syndrome appears to be very rare and only a few isolated reports exist in the literature ${ }^{2-13}$. Divekar et al. reported only 1 case 
of CST out of 700 children with nephrotic syndrome followed over a period of 17 years ${ }^{6}$.

The diagnosis of CST should be considered in any patient with nephrotic syndrome who develops neurologic symptoms. Those are different between the neonate and nonneonate groups. In the latter, the clinical findings are similar to those reported in adults: a decreased level of consciousness, headache and focal neurological signs such as hemiparesis and cranial-nerve palsies. In contrast, the primary neurologic manifestations in neonates are seizures and diffuse neurologic signs ${ }^{14}$. We have found, however, only one case of CST associated with congenital nephrotic syndrome'.

Physical examination may reveal findings of increased intracranial pressure or focal deficits as previously described. Our patient presented papilledema and meningeal irritation signs, both secondary to intracranial hypertension. Lumbar puncture should be done if infection is suspected but is non diagnostic for CST. The CSF may show increased pressure and mildly increased red blood cells due to microhemorrhages. Other nonspecific findings described are increased erythrocyte sedimentation rate and mild leukocytosis. EEG findings are nonspecific ${ }^{15}$.

In the presence of the appropriate clinical history, cranial CT provides an excellent screening procedure. In most cases, as the one presented here, a diagnosis of sinus thrombosis can be made on the basis of the CT findings. The noncontrast-enhanced scan may show the presence of small ventricles, cerebral swelling, hemorrhagic and ischemic infarcts, intracerebral hematomas, the dense-triangle sign and the cord sign. The contrast enhanced scan can disclose the so-called empty delta sign, gyral or tentorial enhancement and dilated transcerebral or medullary veins ${ }^{17}$.

MRI with magnetic resonance venography, because of its noninvasiveness and high sensitivity, is the preferred modality for diagnosis and follow-up of cerebral venous thrombosis. The normal flow void seen in veins and sinuses on noncontrast-enhanced $M R I$ is replaced by signals that are hyperintense or isointense to brain, depending on the sequence utilized and the age of the thrombus ${ }^{18}$.

The treatment of choice is heparin, followed by oral anticoagulation, administered as long as the patient has nephrotic proteinuria, an albumin level below $2 \mathrm{~g} / \mathrm{dL}$, or both ${ }^{16}$. Difficulty in anticoagulation was encountered in our case as in all cases reported in the literature. Loss of ATIII in the nephrotic urine may be an important cause of the failure of anticoa- gulation with heparin. Large amounts of administered heparin may also be lost in the nephrotic uri$n \mathrm{e}^{16}$. Fresh frozen plasma was given to correct antithrombin-3 levels in some reported cases with a good response (reduction of time to achieve the desire anticoagulation level) $)^{2,4,6,12}$. The long-term neurologic outcome of sinovenous thrombosis in children is unclear and the best available estimate is that after a mean of 2.1 years, 77 percent of neonates and 52 percent of nonneonates are neurologically normal ${ }^{19}$. Early recognition, immediate institution of anticoagulation therapy and control of nephrotic syndromeare essential measures to ensure a good prognosis.

Acknowledgments - We wish to thank the pediatric housestaff for providing medical care for this patient and Dr. Marcelo Freire for preparing the images and reviewing of text.

\section{REFERENCES}

1. Mehls O, Andrassy K, Koderisch J, Herzog U, Ritz E. Hemostasis and thromboembolism in children with nephrotic syndrome: differences from adults. J Pediatr 1987;110:862-867.

2. Lau SO, Bock GH, Edson JR, Michael AF. Sagittal sinus thrombosis in the nephrotic syndrome. J Pediatr 1980;97:948-950.

3. Delmas MC, Cochat P, Ranchin B, et al. Thrombose du sinus longitudinal supérieur et embolie pulmonaire au cours d'une néphrose. Pédiatrie 1992;47:31-35.

4. Freycon MT, Richard O, Allard D, Damon G, Reynaud J, Freycon F. Thrombose des sinus veineux intracrâniens au cours d'un syndrome néphrotique. Pédiatrie 1992;47:513-516.

5. Casteels K, Demaerel P, Proesmans W. Clinical quiz. Pediatr Nephrol 1995;9:247-249.

6. Divekar AA, Ali US, Ronghe MD, Singh AR, Dalvi RB. Superior sagittal sinus thrombosis in a child with nephrotic syndrome. Pediatr Nephrol 1996;10:206-207.

7. de Saint-Martin A, Terzic J, Christmann D, Knab MC, Peter MO, Fischbach M. Thrombose du sinus longitudinal et syndrome néphrotique: évolution favorable sous héparine de faible poids moléculaire. Arch Pédiatr 1997;4:849-852.

8. Mandai K, Tamaki N, Kurata H, Fukada Y, Iijima I, Nakamura H. A case of intracranial hemorrhage following superior sagittal sinus thrombosis associated with nephrotic syndrome. No Shinkei Geka 1997;25:1101-1103.

9. Fofah O, Roth P. Congenital nephrotic syndrome presenting with cerebral venous thrombosis, hypocalcemia, and seizures in the neonatal period. J Perinatol 1997;17:492-494.

10. Tullu MS, Deshmukh CT, Save SU, Bhoite BK, Bharucha BA. Superior sagittal sinus thrombosis: a rare complication of nephrotic syndrome. J Postgrad Med 1999;45:120-122.

11. Meena AK, Naidu KS, Murthy JM. Cortical sinovenous thrombosis in a child with nephrotic syndrome and iron deficiency anemia. Neurol India 2000;48:292-294.

12. Pirogovsky A, Adi M, Dagan A et al. Superior sagittal sinus thrombosis: a rare complication in a child with nephrotic syndrome. Pediatr Radiol 2001;31:709-711.

13. Lin CC, Lui CC, Tain YL. Thalamic stroke secondary to straight sinus thrombosis in a nephrotic child. Pediatr Nephrol 2002;17:184-186.

14. deVeber G, Andrew M, Adams C, et al. Cerebral sinovenous thrombosis in children. N Engl J Med 2001;345:417-423.

15. Imai WK, Everhart R, Sanders JM. Cerebral venous sinus thrombosis: report of a case and review of the literature. Pediatrics 1982;70:965-970.

16. Orth SR, Ritz E. The Nephrotic Syndrome. N Engl J Med 1998;338:1202-1211.

17. Rao KCVG, Knipp HC, Wagner EJ. Computed tomographic findings in cerebral sinus and venous thrombosis. Radiology 1981;140:391-398.

18. Medlock MD, Olivero WC, Hanigan WC, Wright RM, Winek SJ. Children with cerebral venous thrombosis diagnosed with magnetic resonance imaging and magnetic resonance angiography. Neurosurgery 1992;31:870-876.

19. deVeber GA, MacGregor D, Curtis R, Mayank S. Neurologic outcome in survivors of childhood arterial ischemic stroke and sinovenous thrombosis. J Child Neurol 2000;15:316-324. 